\title{
BARREIRAS AO ACESSO À SAÚDE NO BRASIL: PRÁTICAS FORMATIVAS À OTIMIZAÇÃO DA PRESTAÇÃO JURISDICIONAL NA SAÚDE À LUZ DE PAULO FREIRE
}

\author{
BARRIERS TO ACESS TO HEALTH IN BRAZIL: TRAINING PRACTICES FOR THE \\ OPTIMIZATION OF JUDICIAL PROVISION IN HEALTH IN THE LIGHT OF PAULO FREIRE
}

Maria da Vitória Costa e Silva ${ }^{1}$

Recebido em 31 de outubro de 2019.

Aprovado em 17 de março de 2020.

RESUMO: Este artigo teve como objetivo analisar as barreiras de acesso à saúde no Brasil. A metodologia foi baseada na análise de referenciais teóricos interdisciplinares, utilizando o método qualitativo. Os resultados mostraram que a constitucionalização de novos direitos, o aumento da demanda por justiça, a ascensão institucional do judiciário, combinada com fatores como a globalização econômica, controle biopolítico e planejamento vertical dos serviços públicos constituem barreiras à otimização das políticas de saúde. Concluiu-se que as práticas de formação formuladas por Paulo Freire, intermediadas pelo Poder Judiciário, podem ser um instrumento efetivo de participação democrática na elaboração do planejamento (vertical e horizontal) dos serviços de saúde e sua efetividade.

Palavras - chave: judicialização da saúde; participação democrática; acesso à saúde; promoção dos direitos humanos.

\begin{abstract}
This article aimed to analyze the barriers of access to health in Brazil. The methodology was based on the analysis of interdisciplinary theoretical references using the qualitative method. The results showed that the constitutionalization of new rights, the increased demand for justice, the institutional rise of the judiciary, combined with factors such as economic globalization, biopolitical control and vertical planning of public services constitute barriers to the optimization of health policies. The conclusion was that the training practices formulated by Paulo Freire, intermediated by the Judiciary, can be an effective instrument for democratic participation in the elaboration of the planning (vertical and horizontal) of health services and their effectiveness.
\end{abstract}

Keywords: judicialization of health; democratic participation; access to health; promotion of human rights.

\section{INTRODUÇÃO}

Este estudo objetivou analisar as principais barreiras que impedem a efetivação dos serviços públicos de saúde no Brasil e, a partir das reflexões de Freire (1996), buscou apresentar possível proposta de melhoria para a prestação jurisdicional, diante das demandas individuais de

${ }^{1}$ Mestre em Prestação Jurisdicional e direitos Humanos (UFT). E-mail: mavitcs@gmail.com 
medicamentos que registram alto impacto econômico, o que pode vir a comprometer o orçamento coletivo.

Ao atentar para o fato de que os serviços públicos estão interligados a fatores políticos, econômicos e sociais, a metodologia aplicada, a princípio, fundamentou-se em conectivos teóricos interdisciplinares.

Importante ressalta-se que a interdisciplinaridade consiste em um novo paradigma contemporâneo presente nas dimensões da epistemologia e da pedagogia, que rompe com uma visão cartesiana e mecanicista do conhecimento, assumindo uma concepção mais integradora, dialética e totalizadora na construção do conhecimento e da prática científica (THIESEN, 2008).

Com isso, em relação às barreiras ao acesso à saúde, foram examinados referenciais teóricos com abordagem jurídica (BARROSO, 2011 e 2013), filosófica (FOUCAULT, 1984 e 2008; HARDT e NEGRI, 2001) e sociológica (SANTOS, 2002, 2007 e 2013), sem desconsiderar demais eixos teóricos sumariados neste artigo.

Quanto à proposta de superação dos entraves detectados no texto como prejudiciais à efetivação dos serviços de saúde, aproveitou-se da contribuição pedagógica de Paulo Freire (1996 e 2019) que trata sobre a importância das práticas formativas para a autonomia libertadora dos atores sociais que são corresponsáveis, ao lado do Estado, por um mundo mais justo e humano.

Além disso, num segundo momento, com o intuito de enriquecer este texto, optou-se por trazer dados sobre a realidade da governança e da gestão em saúde no setor público, constante dos acórdãos (1.130/2017 e 1787/2017 - TCU - Plenário) do Tribunal de Consta da União (BRASIL, TCU, online), que enaltecem a precariedade do sistema de saúde e seu alto custo.

Por fim, também foram examinadas dissertações de mestrado (FARHI NETO, 2007 e LOPES, 2013) disponíveis na internet com os descritores "saúde pública e biopoder", que dimensionam a preocupação em relação à globalização econômica neoliberal e enfatizam a essencialidade do conhecimento crítico e construtivo com o propósito de encontrar novos instrumentos que conduzam ao progresso econômico e social.

Os resultados evidenciaram que a constitucionalização de novos direitos; o aumento da demanda por justiça e a ascensão institucional do Judiciário, aliados ao planejamento vertical das políticas públicas; à globalização neoliberal, instrumentalizada pelo controle biopolítico (modelo científico-político de governabilidade visa disciplinar a coletividade por meio de biopoderes locais), constituem barreiras ao acesso à saúde.

Contexto que, além de estimular as demandas individuais por medicamentos, pode vir a comprometer o orçamento coletivo destinado as demais políticas sociais. Cenário que requer o desenvolvimento de novos mecanismos hábeis que otimizem a prestação jurisdicional no âmbito do acesso à saúde e minimizem sua judicialização.

Nesse sentido, as práticas formativas, defendidas por Paulo Freire (1996), ao permitirem a autonomia libertadora da sociedade, alicerçada num processo contínuo de formação/ação, em que saberes e experiências vividas pela comunidade são respeitados em uma interlocução dialógica com o poder público, podem-se configurar em instrumento adequado a viabilizar o acesso à saúde de qualidade no Brasil.

\section{CONTEXTUALIZAÇÃO DO FENÔMENO DA JUDICIALIZAÇÃO DA SAÚdE E O ENGESSAMENTO DAS POLÍTICAS PÚBLICAS E DOS DI- REITOS HUMANOS}


A crise no setor público de saúde tem motivado críticas da sociedade brasileira. Na internet, essa forma de contestar também é promovida por meio do humor artístico, como se vê abaixo, na Figura 1 (HUMOR ARTÍSTICO, 2019, online).

No mesmo sentido, a letra da música "Sem Saúde", do cantor e compositor Gabriel, O Pensador, abaixo descrita, revela não só a linguagem popular simples e desapegada de sua forma oficial, mas também evidencia a angústia, a dor e o desespero das pessoas carentes que precisam dos serviços públicos de saúde no Brasil.

Figura 1 - Visão crítica dos internautas e humor artístico sobre o caos na saúde pública brasileira.

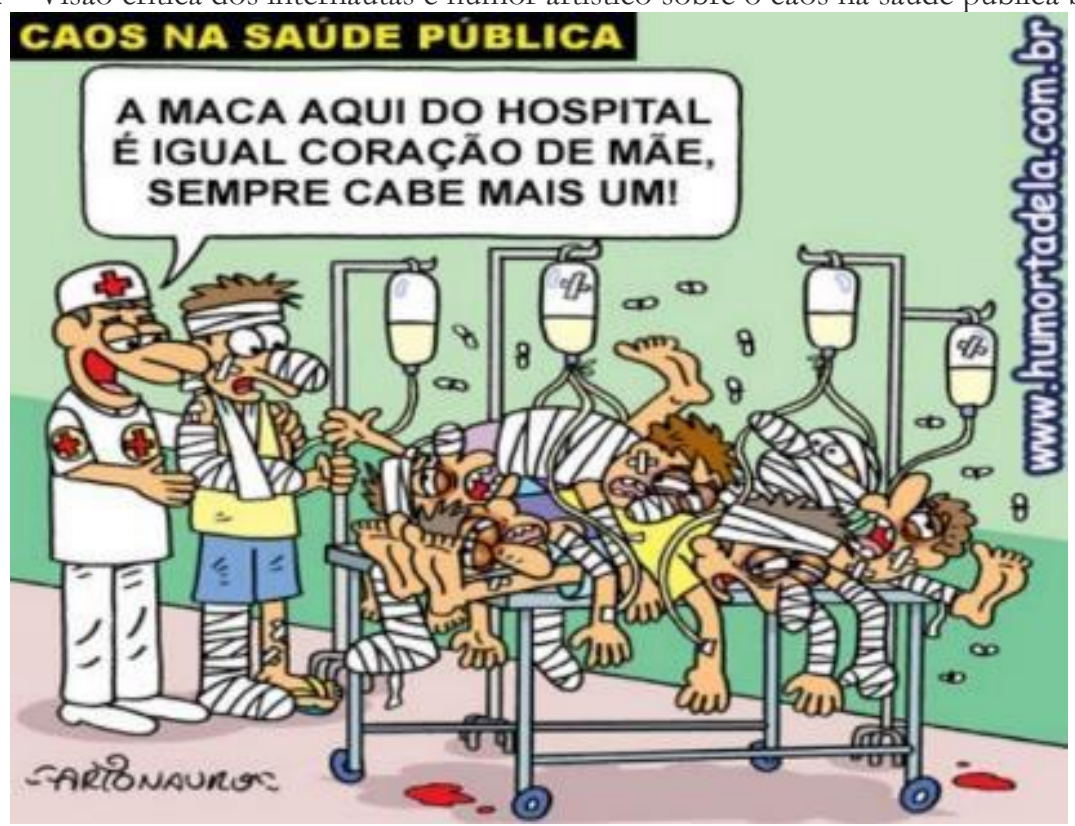

(Gabriel O Pensador, letra música "Sem Saúde”)

Pelo amor de Deus alguém me ajude!

Eu já paguei o meu plano de saúde

Mas agora ninguém quer me aceitar

E eu tô com dô, dotô, num sei no que vai dá!

Emergência! Eu tô passando mal

Vô morrer aqui na porta do hospital

Era mais fácil eu ter ido

Direto pro Instituto Médico Legal

Porque isso aqui tá deprimente, doutor

Essa fila tá um caso sério

Já tem doente desistindo de ser atendido

E pedindo carona pro cemitério

E aí, doutor? Vê se dá um jeito!

Se é pra nós morrê nós qué morrê direito

Me arranja aí um leito que eu num peço mas nada

Mas eu num sou cachorro pra morrer na calçada

Eu tô cansado de bancar o otário

Eu exijo pelo menos um veterinário

Me cansei de lero lero 
Dá licença mas eu vou sair do sério

Quero mais saúde

Me cansei de escutar

- Doutor, por favor, olha o meu neném!

Olha doutor, ele num tá passando bem!

Fala, doutor! O que é que ele tem!?

- A consulta custa cem.

- Ai, meu Deus, eu tô sem dinheiro

- Eu também! Eu estudei a vida inteira pra ser doutor

Mas ganho menos que um camelô

Na minha mesa é só arroz e feijão

Só vejo carne na mesa de operação

Então eu fico 24 horas de plantão

Pra aumentar o ganha pão

Uma vez, depois de um mês sem dormir

Fui fazer uma cirurgia

E só depois que eu enfiei o bisturi

Eu percebi que eu esqueci da anestesia

O paciente tinha pedra nos rins

E agora tá em coma profundo

A família botou a culpa em mim

E eu fiquei com aquela cara de bunda

Mas esse caso não vai dar em nada

Porque a arma do crime nunca foi encontrada

O bisturi eu escondi muito bem

Esqueci na barriga de alguém

Me cansei de lero lero

Dá licença mas eu vou sair do sério

Quero mais saúde

Me cansei de escutar

Socorro! Enfermeira! Urgente!

Tem uma grávida parindo aqui na frente!

Ninguém me deu ouvidos

E eu dei um nó no umbigo do recém-nascido

Mas o berçário tá cheio então eu fico

Com o bebê no meu colo aqui no meio da rua

E lá dentro o doutor tá botando o paciente no colo

- Por favor, fique nua!

- Quê isso doutor?! Tem certeza?

- Confie em mim. É terapia chinesa. Tira a roupa!

- Mas é só dor de dente

- Então abre a boca! (Ahhh) Beleza!

- Ai, doutor, tá doendo!

- É isso mesmo, o que arde cura

- Não! Para! Não! Para doutor! Não pára, doutor! Ai... Que loucura!

- Pronto, passou, tudo bem.

Volta na semana que vem!

Ela vai voltar pra procurar o doutor

Essa vai voltar, pode escrever! 
Mas só daqui a nove meses

Com um filho da consulta na barriga querendo nascer

Me cansei de lero lero

Dá licença mas eu vou sair do sério

Quero mais saúde

Me cansei de escutar

Que calamidade!

Dos bebês que nascem virados pra lua

E conseguem um lugar na maternidade

A infecção hospitalar mata mais da metade

E os que sobrevivem e não são sequestrados Devem ser tratados com todo o cuidado

Porque se os pais não tem dinheiro pra pagar hospital

Uma simples diarreia pode ser fatal

- Come tudo, meu filho, pra ficar bem forte

- Ah, mãe! Num aguento mais farinha!

- Mas o quê que tu quer? Se eu num tenho

nem talher?

- Pô, faz um prato diferente, maínha!

- Eu ia fazer a tal da 'autopsia

Mas eu não tenho faca de cozinha!

- Tá muito sinistro! Alô, prefeito, governador, presidente, ministro, traficante, Jesus Cristo, sei lá

Alguma autoridade tem que se manifestar!

Assim num dá! Onde é que eu vou parar?

Numa clínica pra idosos? Ou debaixo do chão?

E se eu ficar doente? Quem vem me buscar?

A ambulância ou o rabecão?

Eu Tô sem segurança, sem transporte, sem trabalho, sem lazer

Eu num tenho educação, mas saúde eu quero ter

Já paguei minha promessa, não sei o que fazer!

Já paguei os meus impostos, não sei pra quê?

Eles sempre dão a mesma desculpa esfarrapada

A saúde pública está sem verba

E eu num tenho condições de correr pra privada

Eu já tô na merda (GABRIEL O PENSADOR, 1997).

Além do humor artístico acima identificado que denuncia a crise no sistema público de saúde, o Tribunal de Contas da União (TCU), no levantamento nacional de governança e gestão em saúde (BRASIL, TCU, online), encontrou achados que enalteceram as deficiências no atual modelo dessas plataformas no país, bem como retratou gastos exorbitantes em medicamentos e outros insumos pagos pelo Ministério de Saúde, Secretarias Estaduais e Municipais, em cumprimento de decisões judiciais. O TCU verificou que, em relação ao perfil, ao volume e ao impacto das ações judiciais, no período de 2008 a 2015, os gastos do Ministério da Saúde saltaram de R\$ 70 milhões para mais de R\$ 1 bilhão, isto é, tiveram um aumento de mais de 1.300\% (Acordão no 1787/2017 - TCU - Plenário).

Ademais, foram encontradas lacunas quanto ao controle, por parte dos gestores públicos, em relação a pagamentos por fármacos sem registro na Agência Nacional de Vigilância Sanitária (ANVISA); falta de adoção de recomendações do Conselho Nacional de Justiça (CNJ), que resultaram em recomendações do TCU ao Ministério da Saúde com vista ao 
melhoramento das políticas públicas de saúde no Brasil (Acórdão no 1.130/2017 - TCU Plenário).

Em síntese, o Gráfico 1 abaixo consta a quantidade de ações relacionadas à saúde ajuizadas contra a União entre 2010 e 2014 e, o Gráfico 2, registram valores gastos pelo Ministério da Saúde no cumprimento de decisões judiciais, em medicamentos, que passou de 70 (setenta) milhões de reais em 2008 para mais de 1 (um) bilhão de reais em 2015.

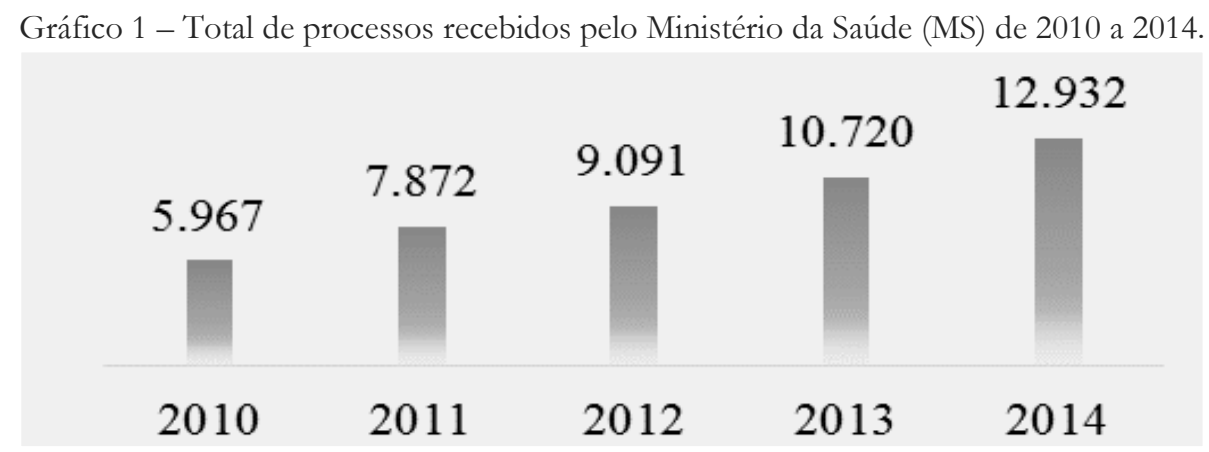

Fonte: Acórdão no 1787/2017 - TCU - Plenário.

Gráfico 2 - Total gasto pelo MS no cumprimento de decisões judiciais, de 2008 a 2015.

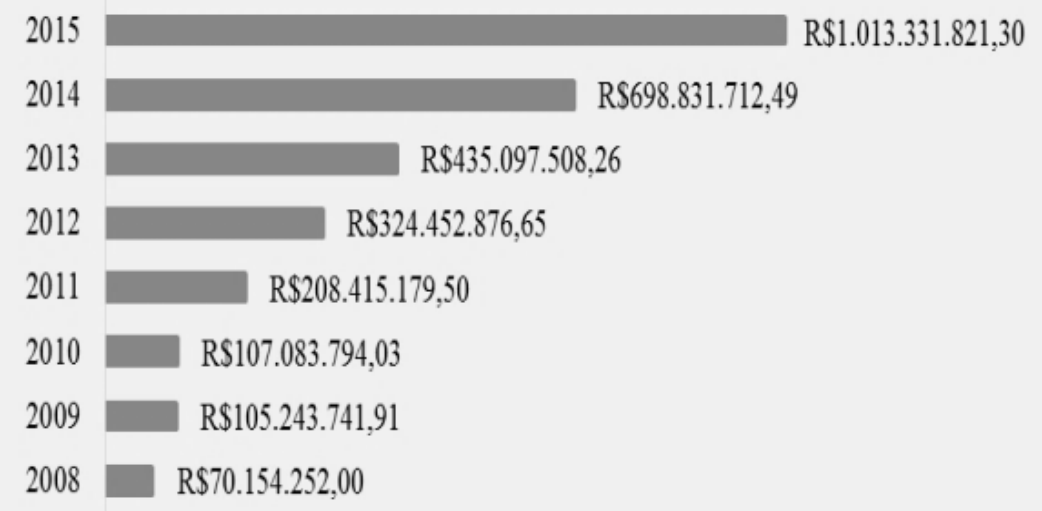

Fonte: Acórdão nº 1787/2017 - TCU - Plenário.

Esses dados, ou seja, a falta de observância, pelos gestores públicos de saúde, das recomendações do Conselho Nacional de Justiça e/ou orientações do Ministério da Saúde; a precariedade do sistema de saúde em nível federal, estadual e municipal têm maximizado as demandas judiciais de saúde, o que pode impactar negativamente no orçamento público destinado aos demais serviços sociais.

Diante desses fatos, este artigo verificou o contexto jurídico, econômico, político e social em que o problema da saúde ganha robustez e quais as principais consequências disto para os direitos fundamentais e humanos, como se demonstrará no próximo tópico.

\subsection{Fatores causais da judicialização política e social: visão jurídica}

Após longo período de violações aos direitos humanos no mundo e no Brasil, com destaque para as agressões cometidas pelo regime militar (1964 a 1972), a Constituição de 1988, consagrou em seu texto os direitos fundamentais, que constituem "patamares mínimos civiliza- 
tórios” (DELGADO, 2015) para a defesa e proteção da dignidade humana a serem concretizados pelo Poder Público, nas esferas municipal, estadual e federal.

A Declaração Universal dos Direitos Humanos de 1948 consolidou a importância da valorização de uma ética fundamental por parte dos Estados, que devem cultivar valores de cunho universal, nas suas relações interna e externa, de proteção à dignidade humana com fundamento nos direitos humanos (PIOVESAN, 2012), pois a vida das pessoas é o vetor central de proteção do ordenamento jurídico moderno, para onde devem convergir os direitos infraconstitucionais. Por isso a ausência de efetivação dos direitos fundamentais nas relações sociais e a falta de mecanismos de defesa dos direitos humanos pelo Estado podem colocar em risco a própria democracia e a vida com dignidade.

Bester (2005a e 2005b) e Sarlet (2005) alertam para o fato de que os direitos fundamentais não podem ser confundidos com a terminologia dos direitos humanos, pois, os direitos fundamentais se aplicam para aqueles direitos do ser humano, reconhecidos e positivados na esfera do direito constitucional positivo de determinado Estado (constitucionais), portanto devem atingir maior grau de efetividade pelo direito interno. Contudo, os direitos humanos guardam relação com documentos de Direitos Internacional, uma vez que se referem a posições jurídicas que se reconhecem ao ser humano como tal, independentemente de sua vinculação com determinada ordem constitucional. São direitos que têm aspiração à validade universal, para todos os povos e tempos, de tal sorte que se revelam um inequívoco caráter supranacional (internacional). Para sua efetivação, dependem da boa vontade cooperativa dos Estados individualmente considerados, o que contribuirá para lograr o atingimento de sua plena eficácia.

Nesse particular, não há dúvida de que os direitos fundamentais, de certa forma, são também direitos humanos, pois seu titular sempre será o ser humano, ainda que representado por entes coletivos, mas não podem ser compreendidos como termos sinônimos. "Os direitos fundamentais, convém repetir, nascem e se desenvolvem com as Constituições nas quais foram reconhecidos e assegurados", o que requer a efetivação na vida cotidiana das pessoas, ou seja, nas relações sociais. (SARLET, 2005, p. 41).

Desse modo, é importante se atentar para o fato de que "a Carta de 1988 situa-se como marco jurídico da transição democrática e da institucionalização dos direitos humanos no Brasil" (PIOVESAN, 2012, p. 59-60). Isto que significa que o Direito brasileiro incorpora os instrumentos internacionais de proteção dos direitos humanos, por isso é obrigado a respeitar os direitos fundamentais à vida digna de seus cidadãos (no seu sentido amplo, incluindo pessoas vulneráveis e carentes).

As nações e a comunidade internacional têm o direito de protestar, ao perceber que algum Estado descumpra os vetores de proteção da dignidade da pessoa humana e dos direitos humanos (PIOVESAN, 2012, p. 59-60).

A partir do conceito de judicialização, torna-se necessária a compreensão dos fatores especificados por Barroso (2012) como motivadores do aumento de demandas judiciais no Brasil. Em sentido restrito a chamada "judicialização da saúde" consiste no aumento de demandas sociais levadas ao Poder Judiciário em decorrência da falta de efetividade das políticas públicas, a cargo dos Poderes Executivo e Legislativo, necessárias à vida com dignidade dos atores sociais.

Em sentido mais amplo, este próprio autor esclarece que a: 
Judicialização significa que algumas questões de larga repercussão política ou social estão sendo decididas por órgãos do Poder Judiciário e não pelas instâncias políticas tradicionais: o Congresso Nacional e o Poder Executivo - em cujo âmbito se encontram o Presidente da República, seus ministérios e a administração pública em geral. Como intuitivo, a judicialização envolve uma transferência de poder para juízes e tribunais, com alterações significativas na linguagem, na argumentação e no modo de participação da sociedade. $\mathrm{O}$ fenômeno tem causas múltiplas. Algumas delas expressam uma tendência mundial; outras estão diretamente relacionadas ao modelo institucional brasileiro. (BARROSO, 2012, online, grifo do autor).

Na dimensão dos novos direitos, Barroso (2011) afirma que vários fatores têm estimulado a judicialização das questões políticas e sociais, que passaram a ter nos tribunais a sua instância decisória final. Para tanto, destaca: i) a constitucionalização de novos direitos; ii) o aumento da demanda por justiça; e, iii) a ascensão institucional do Judiciário; circunstâncias que propulsionam o uso da via judicial.

Assim, Barroso (2012, online) passa a discorrer sobre essas causas, a saber:

a) a redemocratização do País, que culminou com a promulgação da Constituição da República Federativa do Brasil em 1988 e, nas últimas décadas, com a recuperação das garantias da magistratura. Com isso, o Judiciário deixou de ser um departamento técnico-especializado e se transformou em um verdadeiro poder político, capaz de fazer valer a Constituição e as leis infraconstitucionais. Nesse aspecto, também ressalta que o ambiente democrático reavivou o espírito de cidadania, com a divulgação e conscientização, por parte de segmentos da população, sobre os novos direitos conferidos à população, sem falar na expansão institucional do Ministério Público e da Defensoria Pública no Brasil. Enfim, registra o autor que: "a redemocratização fortaleceu e expandiu o Poder Judiciário, bem como aumentou a demanda por justiça na sociedade brasileira";

b) a segunda fase em tal processo, alerta Barroso que se deu com a constitucionalização de inúmeras matérias que antes eram deixadas para o processo político majoritário e para o legislador ordinário. A partir do momento em que uma questão social é disciplinada em uma norma constitucional, ela se transforma em força viva obrigatória, com potencial, em uma pretensão jurídica, que pode ser questionada por meio de ação judicial; e,

c) a terceira e última causa da judicialização, refere-se ao sistema brasileiro de controle de constitucionalidade, que com seu caráter híbrido ou eclético, combina aspectos de dois sistemas diversos, o americano (pelo qual qualquer juiz ou tribunal pode deixar de aplicar uma lei ao caso concreto que lhe tenha sido submetido, por considerá-la inconstitucional) e o modelo europeu (que possibilitou inserir na Constituição brasileira o controle por ação direta, o qual permite que determinadas matérias sejam levadas, em tese e imediatamente, ao Supremo Tribunal Federal), conferindo a ampliação, inclusive, do direito de propositura amplo, previsto no art. 103 da Constituição Federal. Com isso, "quase qualquer questão política ou moralmente relevante pode ser alçada ao STF”.

Ademais, infere-se que a Constituição Federal tem força normativa. Para Hesse (1991, p. 19-20), essa peculiaridade requer a implementação de alguns "pressupostos que permitem à Constituição desenvolver de forma ótima a sua força normativa”, quais sejam:

a) o seu conteúdo deve levar em conta não só os elementos sociais, políticos e econômicos dominantes, mas também deve incorporar o estado espiritual de seu tempo, para que encontre o apoio, a adesão e a defesa da consciência geral; norteadas por princípios fundamentais que se mostrem em condições de serem efetivados nas relações sociais. 
b) a força normativa da Constituição depende, não só de seu conteúdo, mas também de sua práxis, o que requer, às vezes, o sacrifício de um interesse em favor da preservação de um princípio constitucional, a fim de fortalecer o respeito à Constituição e garantir um bem da vida indispensável à essência do Estado Democrático. Ensina Hesse (1991) também ser perigoso para a força normativa da Constituição, a tendência frequente da revisão constitucional, o que abala sua confiança. "A estabilidade constitui condição fundamental da eficácia da Constituição"; e, por fim,

c) "(a) interpretação constitucional está submetida ao princípio da ótima concretização da norma”, por isso não pode estar distante dos fatos concretos de seu tempo.

Para Sarmento (2004, p. 155), em decorrência da força normativa da Constituição, os direitos fundamentais têm eficácia irradiante por todo o ordenamento jurídico, condicionando a interpretação das normas e atuando como impulsos/diretrizes para o legislador, a administração e o judiciário. Essa eficácia enseja a humanização da ordem jurídica, "ao exigir que todas as normas sejam, no momento da aplicação, reexaminadas pelo operador do direito com novas lentes, que terão as cores da dignidade humana, da igualdade substantiva e da justiça social".

Barroso (2011, p. 407) mostra que a CF de 1988 aumentou a demanda por justiça na sociedade brasileira, pela redescoberta da cidadania e pela conscientização das pessoas em relação aos próprios direitos, bem como pela ascensão institucional do Poder Judiciário, que deixou de ser um departamento técnico especializado e passou a desempenhar um papel político, dividindo espaço com o Legislativo e o Executivo.

Nesse aspecto, percebe-se que a judicialização de fato existe; não decorreu de uma opção ideológica, filosófica ou metodológica do Supremo Tribunal Federal, mas limitou-se a cumprir, de modo estrido, o seu papel constitucional, delineado em conformidade com o desenho institucional vigente. (BARROSO, 2012, online).

À luz dos ensinamentos de Barroso (2012, online), hoje Ministro do Supremo Tribunal Federal, os "riscos da judicialização e, sobretudo, do ativismo ${ }^{2}$ envolvem a legitimidade democrática, a politização da justiça e a falta de capacidade institucional do Judiciário para decidir determinadas matérias". Contudo, o Poder Judiciário, segundo esse autor, é o guardião da Constituição, portanto, deverá fazê-la valer, em nome dos direitos fundamentais e valores e procedimentos democráticos, inclusive em face dos outros Poderes. Suas decisões, no caso, devem respeitar a racionalidade, a motivação, a correção e a justiça.

Assim, aos poderes constituídos cabem as tarefas de cumprir cada um as suas competências, disciplinadas na Constituição da República Federativa do Brasil, pois em havendo violação da norma constitucional, o Poder Judiciário deverá intervir para fazer valer os preceitos constitucionais.

Nesse caso, a atividade do Poder Judiciário brasileiro moderno, segundo Appio (2011, p. 63-66) divide-se em dois segmentos básicos (função jurídica e função política) e o controle das políticas públicas. Em síntese, ensina o autor:

a) em relação à função jurídica, o Judiciário atua como representante do Estado, com prerrogativas funcionais e limitações estatutárias, com o fim de assegurar sua isenção frente ao

\footnotetext{
2 Termo metafórico, cunhado em um dia imaginário por um famoso e importante historiador americano chamado Arthur Schlesinger Jr. que, em 1947, fazendo um bico de jornalista para a revista Fortune, escreveu e cunhou a expressão que viria a se identificar como "judicial activism", porém tal fato sequer mereceu destaque no seu mais famoso registro obituário bibliográfico, escrito por MATTSON, Kevin. Arthur Schlesinger Jr.: biographical memoirs. Proceedings of tne American Philosophical Society, v. 153, n. 1, 2009. Conforme PADUA (2015, p. 135).
} 
caso concreto. Incumbindo-lhe, neste aspecto, resolver os conflitos de interesses individuais/ coletivos, lides, ou seja, litígios não afetos às políticas governamentais;

b) em relação à função política, a qual interessa a este estudo, o Judiciário tem atribuições de controle político da atividade dos outros poderes constituídos (Legislativo e Executivo), a partir dos valores constantes da Constituição Federal;

c) o controle das políticas públicas - neste aspecto o Poder Judiciário assume a função política de controle dos atos do Poder Legislativo e Executivo que, também, estão vinculados a deveres e objetivos traçados pela Constituição Federal de 1988.

As políticas públicas, neste aspecto, podem ser compreendidas como:

Instrumentos de execução de programas políticos baseados na intervenção estatal na sociedade com a finalidade de assegurar as condições materiais de uma existência digna a todos os cidadãos. [...] As políticas públicas no Brasil se desenvolvem, portanto, em duas frentes, quais sejam, políticas públicas de natureza social e de natureza econômica, ambas com um sentido complementar e uma finalidade comum, qual seja, de impulsionar o desenvolvimento da Nação, através da melhoria das condições gerais de vida de todos os cidadãos. (APPIO, 2011, p. 136).

É neste contexto que a fenômeno da judicialização da saúde começou a ganhar forma, pois a Constituição de 1988 ao garantir, no seu art. 196, a saúde como direito de todos e dever do Estado e, ao disciplinar no inciso XXXV do art. $5^{\circ}$, que a lei não excluirá da apreciação do Poder Judiciário a lesão e/ou a ameaça ao direito, confere à pessoa lesada, no seu direito à saúde, a possibilidade de socorrer-se da via judicial para resguardo da tutela ao direito à saúde, que deveria ser respeitado e garantido pelo Estado com o desenvolvimento de políticas públicas de inclusão social.

O direito à saúde básica é imprescindível à vida com dignidade e seu desrespeito acarreta outras violações aos direitos humanos, como o direito à cidadania e à liberdade, o que, por consequência, afeta a condição humana como um todo.

Celso Lafer (1997), ao trazer à luz as reflexões de Hannah Arendt, leciona que essa filósofa preconizou que a cidadania deve ser compreendida não como um fato e um meio, mas como um princípio, tendo em vista que a privação da cidadania afeta a condição humana, uma vez que:

(...) o ser humano privado de suas qualidades acidentais - o seu estatuto político - vê-se privado de sua substância, vale dizer: tornado pura substância, perde a sua qualidade substancial, que é de ser tratado pelos outros como um semelhante. (1997, p. 151, grifos do autor).

A cidadania para Arendt consiste, segundo esse autor brasileiro, no "primeiro direito humano que a polis como um artefato humano pode conceder, e do qual derivam todos os demais, é o direito à vida pública, que permite o comando da palavra e da ação [...] é o direito a ter direitos". (Lafer, 1997, p. 151).

A reconstrução da cidadania, a conscientização dos direitos fundamentais sociais consagrados constitucionalmente no Brasil e a ascensão institucional do Judiciário, que de intérprete da lei passa a desempenhar, também, um papel político de realizar a Constituição, têm estimulado o aumento das demandas judiciais, mormente para fazer valer a garantia do direito à saúde, como patamar mínimo civilizatório à vida com dignidade.

É certo que para a concretização desses direitos fundamentais no campo das relações sociais 
também haverá momentos de tensão, principalmente com a descoberta de novas tecnologias e dos meios de comunicação controlados pela globalização econômica neoliberal que tende a suplantar o Estado de Direito e a Política.

Neste aspecto, o próximo eixo temático se propôs a refletir acerca dos efeitos da globalização econômica neoliberal sobre: o direito à saúde, a dignidade da pessoa humana e os direitos humanos, com apoio em estudos científicos publicados em revistas, periódicos, livros e sítios da internet que revelam a preocupação de Foucault com o surgimento da sociedade de controle, de natureza biopolítica (novo paradigma do poder, surgido no final do século XIX e início do século XX, que se instalou no mundo contemporâneo com o objetivo de instrumentalizar a vida humana coletivamente, por meios de práticas disciplinares - biopoderes locais). Essa reflexão tem o fim de evitar a ressuscitação de um novo Estado totalitário de desprezo à vida humana.

\subsection{A globalização econômica neoliberal e o biopoder foucaultiano: paradigmas de fragilização das políticas de saúde e dos direitos humanos}

Ao lado dos fatores descritos por Barroso (2011, p. 407) como fundantes da judicialização, no início do século XXI, constatam-se avanços, sem precedentes, dos meios de comunicação, das novas tecnologias e das relações econômicas, que tomam contornos diferentes à defesa da dignidade da vida, uma vez que surge novo paradigma de controle do poder econômico, que Foucault chama de biopoder (HARDT; NEGRI, 2001, p. 43).

Para melhor compreender o que vem a ser o biopoder e o que esse termo tem a ver com as barreiras ao acesso à saúde, percorrem-se as lições de Hardt e de Negri (2001, p. 42), que, com riqueza de detalhes, esclarecem o pensamento foucaultiano, o qual, ao fazer uma abordagem histórica sobre a governabilidade nos séculos XIX e XX, registra o nascimento da biopolítica (2008) e a transição da sociedade disciplinar para a sociedade de controle, que se concretiza por micropoderes distribuídos sistemicamente na sociedade (FOUCAULT, 1984).

A globalização neoliberal, para Boaventura de Sousa Santos, corresponde:

(...) à nova forma do modo de acumulação do capital, que encolhe o espaço público e expande o espaço privado, afirma a racionalidade em si do mercado, fragmenta o trabalho produtivo submetendo-o às exigências impostas pelo capital financeiro, leva à desagregação das formas de sociabilidade e ao esgarçamento do tecido social e político sob os efeitos de uma distribuição profundamente desigual de custos e de oportunidades em todo o sistema mundial, com o aumento exponencial das desigualdades entre países ricos e pobres e com a formação de bolsões de miséria e opulência no interior de um mesmo país (2013, p. 30).

É nesse aspecto que Hardt e Negri (2001) referem-se ao termo utilizado por Foucault (2008) conhecido por biopolítica (modelo científico-político que consiste na prática disciplinar utilizada para governar coletivamente os indivíduos, por meio de biopoderes locais). Para tanto, elucidam que, se na sociedade disciplinar o poder visava a governar o indivíduo; na sociedade de controle, concebida por Foucault (2008), o poder tem por alvo o conjunto dos indivíduos, ou seja, a população.

Além disso, se na sociedade disciplinar a força motriz do comando social era construída por aparelhos estatais de regulação e disciplina dos costumes, hábitos e práticas produtivas individualizadas, visando a obediência às regras impostas pelo Estado, objetivando uma vida 
harmônica socialmente. Com o surgimento da biopolítica, o foco não é mais o corpo individualizado, mas o corpo coletivo, a população. A biopolítica representa micropoderes locais prática de biopoderes distribuídos por todos os lugares, não há lugar privilegiado (FOUCAULT, 1984).

Assim funciona a sociedade de controle, que traz sérias preocupações para os direitos fundamentais e humanos, haja vista que a descoberta de novas tecnologias e a globalização neoliberal, acelera o processo biopolítico, pois muitas vezes essas descobertas são manipuladas por micropoderes locais que se encontram em vários lugares ao mesmo tempo, distribuídos por uma rede de mecanismos que envolvem toda a estrutura da sociedade. São formas de poderes diferentes do Estado, não está localizado exclusivamente no aparelho de Estado (FOUCAULT, 1984).

Os estudos de Foucault permitiram reconhecer a natureza biopolítica do novo paradigma do poder que se instalou no mundo contemporâneo, no final do século XIX e início do século $\mathrm{XX}$, quando explicou o que vinha a ser o biopoder. Deste modo esclarece Hardt e Negri que o:

Biopoder é a forma de poder que regula a vida social por dentro, acompanhando-a, interpretando-a, absorvendo-a e a rearticulando. O poder só pode adquirir comando efetivo sobre a vida social total da população quando se torna função integral, vital, que todos os indivíduos abraçam e reativam por sua própria vontade. Como disse Foucault, 'a vida agora se tornou objeto de poder'. A função mais elevada desse poder é envolver a vida totalmente, e sua tarefa primordial é administrá-la. O biopoder, portanto se refere a uma situação na qual o que está diretamente em jogo no poder é a produção e a reprodução da própria vida. (HARDT; NEGRI, 2001, p. 43).

Com a globalização econômica, observa-se maior instrumentalização da vida humana. "Vivemos numa época em que quase tudo pode ser comprado e vendido. Nas três últimas décadas, os mercados - e os valores de mercado - passaram a governar nossa vida como nunca. Não chegamos a essa situação por escolha deliberada” (SANDEL, 2013, p. 11).

Em uma sociedade de controle a vida humana é facilmente comandada pelos valores de mercado que, segundo Sandel (2013, p. 13), passaram a desempenhar um papel cada vez maior na vida social. A economia torna um domínio imperial, em que a lógica da compra e da venda não se aplica apenas a bens materiais, mas governa a própria vida humana como um todo. É o que se observa com a proliferação de escolas, hospitais e prisões inseridos no sistema da busca do lucro; a indústria da guerra que ganha com a venda de armamentos, de alimentos e de medicamentos. Estes alertas também foram trabalhados por Foucault (2010) em seu clássico livro "Vigiar e punir".

Em uma rápida consulta na internet, ao considerar os descritores "saúde pública e biopoder", surgem como resultados vários trabalhos científicos preocupados com o fortalecimento desse novo paradigma de poder, que se intensifica com a onda consumerista por quase todos os quadrantes do globo terrestre. Neste aspecto, duas dissertações de mestrado, dentre tantas outras, chamam a atenção, sendo os trabalhos de Luiz Fernando Lopes, cujo tema é "Medicalização de crianças com queixa escolar e o Núcleo de Apoio à Saúde da Família (NASF): uma análise crítica", e de Leon Farhi Neto, na temática "Biopolítica em Foucault".

No primeiro trabalho, Lopes (2013, p. 17) registra certa preocupação com as estratégias com que a classe dominante utiliza o saber científico: a) um dos interesses refere ao fazer da 
ciência uma geradora de tecnologia e riqueza material para os afiliados ao estrato social hegemônico; e, b) o outro interesse diz respeito à transformação do discurso científico em ferramenta para o controle e a subserviência das camadas sociais subalternas, que são submetidas à esfera estratégica do biopoder.

Lopes (2013, p. 18-19, grifo do autor) afirma que, se "o exercício do biopoder é o objetivo traçado pelos setores sociais hegemônicos, é necessária uma estratégia para operacionalizar esse projeto, o que justifica a existência do que Foucault denomina biopolítica”. Como exemplo emblemático, o autor alerta para o fato que:

Uma das expressões mais evidentes de biopolítica é a medicalização da vida, um fenômeno que se faz presente no momento em que o saber médico se insinua para ocupar espaços não relacionados à terapia, tomando de assalto diversos domínios da vida reservados ao debate político, às questões de classe e às disputas de sentido de plano coletivo [...] o biopoder convoca as estratégias biopolíticas para gerir a vida dos indivíduos; essas estratégias se manifestam através da medicalização, uma proposta anacrônica que reduz todas as querelas sociais e sofrimentos humanos a problemas biológicos (biologização), silenciando os tensionamentos de classe para revigorar e favorecer a manutenção do biopoder. (2013, p. 18).

No segundo texto, Leon Farhi Neto (2007, p. 131-132) remonta aos estudos de Foucault, ocorridos entre 1974 e 1979, nos quais traça cinco formulações da biopolítica que, a princípio, mostram como cada uma dessas realidades naturais da vida humana emerge e é agenciada no interior de práticas político-discursivas, quais sejam: a saúde, a raça, a sexualidade, a segurança e a economicidade. "Cada um desses aspectos da vida humana é um modo de objetivação, ao qual se articula um modo de assujeitamento. A naturalidade da população é a protuberância à qual se agarram os diferentes poderes [...]".

Nesse aspecto, Farhi Neto assevera que:

A tecnologia propriamente biopolítica é o mecanismo de poder que lida com o todo da população, que desenvolve os instrumentos prático-discursivos para agenciar a vida da espécie humana, não por uma ação direta sobre o corpo de cada um dos seus elementos, não por uma intervenção imediata sobre as vidas individuais dos elementos que compõem o conjunto de uma população, mas por uma ação sobre as variáveis ambientais que condicionam a vida da população, por uma intervenção mediada pelas determinações naturais que têm uma implicação causal sobre a ordem da população. $\mathrm{O}$ mecanismo de poder biopolítico age não diretamente sobre os indivíduos constituintes da população, mas sobre o meio em que estão inseridos, cujas diversas variáveis são condicionantes de uma situação, de um estado da população. Dessa maneira, a biopolítica, no tocante à saúde da população, age sobre o planejamento espacial dos diversos aparelhos urbanos, a renovação do ar, as canalizações de água e esgoto, a localização de cemitérios, abatedouros, hospitais, desenvolve programas de saúde e campanhas públicas que visam à população como um todo. (2007, p. 132-133, grifo nosso).

A lógica do Estado de Direito, responsável pelo equilíbrio entre os fatores políticos e econômicos, quando se encontra com suas instituições fragilizadas e corrompidas por valores antiéticos, como os da corrupção sistêmica, facilmente será suplantada pela lógica do biopoder. Este, ao manter o controle do Estado do Direito e da política, instrumentaliza a vida humana. Nota-se que, nesta lógica, o homem não é mais o fim, mas o meio para a ascensão do capital e da concentração de riquezas por empresas multinacionais. 
As matérias dos noticiários dos jornais, revistas, televisão e rádio no Brasil, têm, como regra geral, dois tipos de discursos: de um lado, propagandas dos governos Estaduais sobre a defesa da saúde de qualidade, com hospitais estruturados e acesso à saúde para todos; de outro, o clamor da sociedade carente morrendo nos hospitais públicos, sem a atenção de qualidade mínima à saúde, o que tem levado parte da população a bater às portas do Poder Judiciário, perseguindo a tutela efetiva do direito à saúde.

Para Santos (2013, p. 43), a "busca de uma concepção contra-hegemônica dos direitos humanos deve começar por uma hermenêutica de suspeita em relação aos direitos humanos tal como são convencionalmente entendidos e defendidos". Infere-se que, na sociedade atual, a vida gira em torno de uma enorme homogeneidade, embora o discurso seja do respeito ao multiculturalismo e defesa dos direitos humanos. Na verdade, o mercado dita as normas de comportamentos e valores que se devem cultivar; a cultura de um povo perde seu espaço e o processo histórico cede lugar para uma vida cíclica, sem razão de ser.

Desse modo, Perius (2013, p. 134-135) utiliza um termo tematizado por Habermas (1987, p. 103-104) conhecido como "o fim das energias utópicas", bastante apropriado para compreender esta época da nova "intransparência". Nesta, por não haver clareza sobre o seu contexto, impossibilita-se ao homem enxergar longe, pois a hegemonia da ordem econômica mundial e a despolitização da economia criam no contexto social uma intransparência perigosa, que condena as pessoas a viverem eternamente no interior deste sistema sem qualquer possibilidade de enxergar para além desse círculo vicioso. Tudo isso é prejudicial porque esteriliza o pensamento político.

Acrescenta Ruiz (2013, p. 35-36) que um dos desdobramentos autoritários mais graves do biopoder dentro do Estado moderno é o chamado estado de exceção (AGAMBEN, 2004), pois permite o controle extremo da vida dentro do Estado de Direito. Isso acontece quando o Estado utiliza a força policial para inibir reivindicações pacíficas e legítimas da população ou suspende os efeitos de uma "Lei" sob a alegação de coibir o terrorismo e o crime organizado, mesmo que ceifando a vida de pessoas inocentes.

Agamben leciona que:

O estado de exceção se caracteriza por suspender, total ou parcialmente, o direito sobre a vida humana. Ao suspender o direito, a vida humana fica reduzida à mera vida natural, é uma vida desprotegida. No estado de exceção, a vida humana se torna totalmente vulnerável e por isso plenamente controlável. O estado de exceção tem: 'um significado biopolítico como estrutura original em que o direito inclui em si o vivente por meio de sua própria suspensão [...]' . (2004, p. 14).

Portanto, o "estado de exceção é uma técnica de controle biopolítico que, ao suspender total ou parcialmente o direito sobre a vida, permite seu controle extremo, inclusive dentro de um Estado de direito" (RUIZ, 2013, p. 36). É nesse contexto que a judicialização da saúde ganha fôlego e congestiona o Poder Judiciário, trazendo sérios impactos sobre o orçamento público e a vida coletiva das pessoas.

À luz do exposto, pode constatar que a globalização econômica neoliberal e o biopoder constituem, também, barreiras ao acesso à saúde de qualidade no Brasil.

Ademais, outro fator preponderante que não permite avanços à efetivação do direito à saúde diz respeito ao modelo de planejamento dos serviços de saúde, pois a maior parte dos municípios brasileiros, além de não ter plataforma de consulta popular para saber quais são as

PRACS: Revista Eletrônica de Humanidades do Curso de Ciências Sociais da UNIFAP https://periodicos.unifap.br/index.php/pracs ISSN 1984-4352 Macapá, v. 13, n. 1, p. 79-102, jan./abr. 2020 
prioridades locais, elabora seu planejamento de forma vertical, conduzido por gestores públicos sem conhecimento sobre gestão ou administração. Estes, não raras vezes escolhidos dentre apaniguados políticos sem visão estratégica de como trabalhar o orçamento municipal, acabam laborando em ambiente que favorece a corrupção com o dinheiro público. É por isto que a participação democrática da sociedade na elaboração e na execução do planejamento tem sido um tema corrente de discursão no meio jurídico e político, razão pela qual merece atenção especial no item que segue.

\subsection{Repolitização do planejamento horizontal como prática democrática}

Neste tópico, o planejamento vertical de saúde é identificado como outro implicador que estimular o aumento das demandas judiciais, tendo em vista que não atende às necessidades básicas das comunidades locais. O Poder Público, ao não priorizar o direito de escuta popular para saber as prioridades dos munícipes, pode vir a formular planos de ação que não atendam aos clamores sociais.

O Poder Executivo, ao privilegiar só a vertente vertical de planejamento, deixando de considerar a força horizontal emergida da comunidade, além de fragilizar a promoção dos direitos sociais no âmbito da saúde, tem sido alvo de inúmeras críticas nas Audiências Públicas de Saúde que o Supremo Tribunal Federal e o Conselho Nacional de Justiça brasileiro têm realizado para debater sobre os mecanismos viabilizadores à minimização da judicialização (BRASIL, CNJ, online).

Guimarães (2008, p. 56), com base em Habermas, assevera que a Constituição de 1988 pode ser vista como propulsora de uma maior participação política da sociedade no processo de tomada de decisões, contribuindo para uma democracia deliberativa e participativa no País, em que os Poderes Públicos precisam disseminar a cultura do diálogo com a sociedade civil, com vista a conduzir melhor as políticas públicas do Estado.

Com isso, é preciso reforçar a efetivação do modelo horizontal de democracia participativa, que estimule a consolidação da democracia, de forma a buscar novas alternativas institucionais para promover, de fato, maior participação dos atuais conselhos sociais, a fim de desburocratizá-los, tornando-os representativos no que diz respeito à participação deliberativa na esfera pública, o que se requer a ampliação de espaços que promovam a conscientização, o aprendizado da democracia e o fomento à criatividade contínua, na forma proposta por Habermas (GUIMARÃES, 2008, p. 104-105).

Segundo Alexandre Bernardino Costa et al, Roberto Lyra Filho criou o termo metafórico "o direito achado na rua", que procurou intensificar e restituir a confiança do poder popular, dando oportunidade à emancipação dos excluídos, para quebrarem-se as algemas que aprisionam o homem na opressão e na espoliação que o aliena na História, para se fazer sujeito ativo, capaz de transformar o seu destino e conduzir a sua própria experiência na direção de espaços libertadores (COSTA; SOUSA JUNIOR , 2009, p. 18).

$\mathrm{O}$ direito à saúde, consagrado constitucionalmente, partiu da articulação desses movimentos sociais, sobretudo nos anos de 1980, em que o movimento pela reforma sanitária se configurou como um dos mais fortes protagonistas no processo constituinte que desaguou na Constituição de 1988 (COSTA; SOUSA JUNIOR, 2009, p. 17).

Santos (2002, p. 5-7), ao examinar a categoria do contrato social da modernidade, reafirma ter este adquirido novos contornos, ao corresponder à constante tensão dialética entre 
regulação social e emancipação social que se reproduz pela polarização constante entre a vontade individual e a vontade geral, ou seja, entre o interesse privado e o bem comum. E, “o direito e a educação cívica são os garantes do desenrolar pacífico e democrático dessa polarização num campo social que se designou por sociedade civil"'.

O clamor social por saúde pública de qualidade no País revela que algo está errado, sobretudo pelo evidente fato de que o planejamento das políticas públicas confeccionado verticalmente não consegue atender o mínimo existencial à vida digna. Portanto, é preciso repolitizar o planejamento horizontal das políticas públicas no Brasil, a partir do desenvolvimento de mecanismos de consulta popular que possibilitem a participação democrática da comunidade nas discussões de interesse público.

O planejamento consiste numa ferramenta jurídica do Direito Administrativo Constitucional brasileiro, capaz de gerar o empoderamento do cidadão, a consensualidade, a governança social e a concretização dos objetivos e metas insculpidos na Constituição Federal, efetivando as políticas públicas sociais a partir das necessidades locais da população (VELOSO, 2014, p. 18).

Ante as ineficiências das políticas públicas no Estado brasileiro, a abordagem sobre o instituto do planejamento pelo direito administrativo, na forma defendida por Veloso (2014), torna-se importante para este estudo, uma vez que o cerne do debate requer que o planejamento do orçamento perpasse pela participação da população.

O êxito do planejamento no âmbito da saúde requer, para sua efetividade e legitimidade, que o mesmo seja compreendido como um instituto jurídico administrativo constitucional que requer a contribuição democrática da população na sua elaboração, até para ter sua eficácia regular.

Nesse contexto, o Poder Executivo, nas esferas federal, estadual e municipal, deve franquear a abertura de espaços públicos para ouvir os líderes comunitários, conselhos municipais dentre outras entidades, franqueando amplo acesso das informações substanciais que dizem respeito ao orçamento público e seus principais entraves.

Paulo Bonavides ressalta que:

A democracia participativa é direito constitucional progressivo e vanguardeiro. É direito que veio para repolitizar a legitimidade e reconduzi-la às suas nascentes históricas, ou seja, àquele período em que foi bandeira de liberdade dos povos. [...] A democracia participativa combate a conspiração desagregadora do neoliberalismo e forma a nova corrente de idéias que se empenham em organizar o povo para apôr um dique à penetração da ideologia colonialista; ideologia de submissão e fatalismo, de autores que professam a tese derrotista da impossibilidade de manter de pé o conceito de soberania. A obsolescência deste é proclamada a cada passo como verdade inconcussa. A democracia participativa porém, se vingar, há de elaborar outro direito constitucional forjado na luta e na rejeição ao neoliberalismo da recolonização. (2008, p. 33-34).

Já Sarmento (2006, p. 282-283) ressalta que o bom funcionamento da democracia estaria ligado à existência do debate público dinâmico e plural sem que esteja submetido ao controle do Estado, nem tampouco ao poder econômico ou político privado.

Nesse sentido, o direito de escuta e de fala devem respeitar ideias contrárias; o debate deve ser impulsionado pela proteção à liberdade de expressão, em busca do consenso que contribua para o bom funcionamento dos serviços públicos.

Sarmento, com base em Habermas (2014), alerta que: 
Na sociedade de massas, houve uma mudança estrutural na esfera pública. Hoje, a opinião pública resulta cada vez menos do embate de idéias entre cidadãos bem informados, sendo cada vez mais definida pelos veículos de comunicação de massa. O sujeito real da democracia contemporânea não é, infelizmente, o cidadão participativo, mas consumidor apático, que, no intervalo entre a novela e o filme enlatado, assiste no jornal da TV às notícias sobre o último escândalo político. (2006, p. 283, grifo nosso).

Habermas (2014, p. 502-506) ao pesquisar sobre o desenvolvimento da esfera pública na Inglaterra, na França e na Alemanha, no período dos séculos XVII ao XX, leciona que, de modo esquemático, confrontam-se dois domínios de comunicação politicamente importantes: por um lado, o sistema de opiniões informais, pessoais e não públicas; noutra vertente, o sistema de opiniões formais, autorizadas institucionalmente. Contudo, "uma opinião pública no sentido rigoroso apenas pode ser produzida quando ambos os domínios da comunicação são mediados por aquela outra publicidade, a publicidade crítica".

Dessa reflexão habermasiana infere-se que a ideia principal da mudança estrutural da esfera pública gira em torno do cultivo do princípio crítico que deve estar presente nos espaços públicos. Consiste no debate racional crítico construtivista, onde o melhor argumento deve prevalecer.

A despeito das mudanças estruturais tais como as promovidas pela promulgação da Constituição de 1988, é notório que a participação popular e o controle social das políticas públicas caracterizem-se como um sério problema que desafia a efetividade dos direitos fundamentais consagrados constitucionalmente. Estamos diante de condições similares às descritas por Foucault (2008) - na sociedade de controle, pois cidadãos que deveriam participar democraticamente no enfrentamento do poder midiático alienador, encontram-se apáticos e presos à reengenharia do biopoder.

Essas, dentre tantas questões, são as principais causas apontadas pelos conectivos teóricos interdisciplinares que têm motivado a judicialização política e social. Processo que intensifica a vulnerabilidade dos direitos humanos e que tem instaurado a desobediência civil legítima, por meio dos movimentos populares que, no Brasil, a partir de junho de 2013 tomou as ruas reivindicando aos Poderes Públicos iniciativas que qualifiquem as políticas públicas e minimizem a corrupção sistêmica com o dinheiro público.

Diante desse cenário, o caminho que se pretende não é o de se curvar aos projetos econômicos neoliberais que restringem direitos fundamentais à dignidade da vida, mas "reinventar a democracia" por meio de novas práticas que estimulem o conhecimento emancipatório contra-hegemônico, que permitam a concretização dos direitos fundamentais no âmbito das relações sociais.

\section{O ACESSO AO DIREITO À SAÚDE: CONTRIBUIÇÃO EDUCACIONAL EM PAULO FREIRE}

Com base nas lições do educador Paulo Freire (1996), sobre a pedagogia da autonomia saberes necessários à prática educativa; este capítulo se propõe a refletir sobre o processo de formação pedagógica que, ao ser conduzido pelo Poder Judiciário, além’ de aproximar os magistrados dos saberes comunitários, pode contribuir-se em medida estratégica para o conhecimento emancipatório da sociedade e a construção de alternativas de sociabilidade que ampliem, não só o acesso às políticas sociais, mas, também, a promoção dos direitos humanos, 
por meio de planos de governos democráticos voltados para o interesse público.

Em relação à judicialização, no momento, caberia ao Poder Judiciário, que se encontra congestionado de demandas perseguindo a tutela do direito de saúde, assumir sua quota-parte de responsabilidade por meio da aproximação com os litigantes ou com autores comunitários e, a partir do direito de escuta, encontrar novos caminhos que levem à minimização desses litígios, a efetivação dos direitos fundamentais e a promoção dos direitos humanos.

A justiça democrática de proximidade, nos termos defendido por Santos (2007), perfaz-se por meio da implantação de novas práticas de acesso à justiça (CAPPELLETTI e GARTH, 2002) que disseminem a cultura dialógica construtivista entre Poder Judiciário e comunidade.

Contudo, como tornar concreto esse processo pedagógico emancipatório de aproximação entre o Estado-Juiz e a sociedade? Responder a esta questão é uma tarefa bastante complexa. Porém Freire (1996), ao analisar o ensino no Brasil, deixou rico legado instrumental para a repolitização não só da educação, mas também da política e da justiça, a partir de práticas formadoras que promovam a autonomia libertadora da sociedade que se constrói pelo processo contínuo de formação/ação, que considera os saberes e as experiências vividas pela comunidade como valorosos contributos para se trabalhar o ensino, as políticas públicas, os projetos que envolvam o interesse público e o futuro do homem em sociedade.

É nesta linha de conteúdos que Paulo Freire defende a pedagogia da autonomia (1996) que deve consubstanciar sua proposta de práticas formativas a serem desenvolvidas no âmbito das articulações entre poderes públicos e sociedade.

Uma das primeiras premissas recomendadas por esse educador está presente na interlocução entre poderes públicos constituídos e sociedade, refere-se ao ato de ensinar a partir de saberes socialmente construído nas relações prática e comunitária, pois o ato de "ensinar não é transferir conbecimento, mas criar as possibilidades para a sua produção ou a sua construção" (FREIRE, 1996, p. 12, grifos do autor).

No mesmo sentido que Freire define o ato de ensinar, a justiça democrática de proximidade que nos propõe o sociólogo Boaventura de Sousa Santos (2007), pode ser conduzida por meio do processo de formação comunitária que respeite o compartilhamento de experiências entre sujeitos, pois quem "forma se forma e re-forma ao for-mar e quem é formado forma-se e forma ao ser formado”. (FREIRE, 1996, p. 12).

As tarefas precípuas da ação educativa-progressista, e por que não dizer das práticas formadoras da comunidade, envolvem o desenvolvimento da curiosidade crítica, insatisfeita, indócil e inquieta num ambiente de confiança, de escuta e respeito dos saberes necessários de todos que estão a dialogar. "Curiosidade com que podemos nos defender de 'irracionalismos' decorrentes ou produzidos por certo excesso de 'racionalidade' de nosso tempo altamente tecnologizado" e com um poder midiático, muitas vezes, a serviço do poder econômico neoliberal (FREIRE, 1996, p. 15).

O estudo de Freire a pedagogia da autonomia: saberes necessários à prática educativa registra alguns eixos facilitadores para contribuir na transformação democrática da justiça, por meio de práticas formadoras, que podem se concretizar pela abertura dialógica entre os operadores do direito, a universidade e a comunidade.

Freire (1996, p. 13-40), aponta alguns eixos essenciais ao processo pedagógico da autonomia que não podem deixar de ser observados, a saber:

1) o processo de formação comunitária deve ocorrer com a máxima proximidade de rigorosa formação ética e estética. Para Freire (1996), transformar a experiência em puro 
treinamento técnico é amesquinhar o que há de fundamentalmente humano no exercício educativo: o seu caráter formador, por isso defende que o ato de ensinar exige estética e ética;

2) ensinar exige a corporificação das palavras pelo exemplo - "Pensar certo é fazer certo". Significa que as palavras não se transformam por sua externalização, mas por meio de sua ação. Praticar comportamentos de valorização ao próximo; respeitar opiniões contrárias, saber conviver com as diferenças, exige-se risco, aceitação do novo e rejeição de qualquer forma de discriminação, principalmente de raça, classe e de gênero que ofenda a dignidade do ser humano. "O pensar certo por isso é dialógico e não polêmico";

3) ensinar exige reflexão crítica sobre a prática, o reconhecimento e a assunção da identidade cultural - uma justiça democrática de proximidade não se faz distante da reflexão crítica dos saberes e experiências vividas pelos grupos sociais. Quanto mais o ser-sujeito se percebe e busca compreender-se como ser, mais torna capaz de mudar, de promover-se. No caso, do estado de curiosidade ingênua passa para o de curiosidade epistemológica. Esse reconhecimento propicia condição para o convívio com o outro, possibilita a assunção da identidade cultural, que o eleva a se assumir como ser social, político e histórico, como ser pensante, comunicante e responsável pelo futuro de sua comunidade, de seu país e do seu planeta;

4) ensinar exige respeito à autonomia do ser do educando e bom senso - "O respeito à autonomia e à dignidade de cada um é um imperativo ético e não um favor que podemos ou não conceder uns aos outros". Nesse sentido, o sujeito pensante e atuante deve respeitar a autonomia, a dignidade e a identidade do outro. E, saber que essa postura o levará inapelavelmente à criação de outras boas práticas, sem as quais aquele saber vira inautêntico, palavreado vazio e inoperante;

5) ensinar exige humildade, tolerância, apreensão da realidade, convicção de que a mudança é possível e que a luta em defesa dos direitos humanos é construída com a colaboração de todos. A capacidade de aprender, não apenas para nos adaptar, mas, sobretudo, para transformar a realidade, para nela intervir, recriando-a para melhorar o convívio, a vida e o meio ambiente saudável às presentes e futuras gerações.

O diálogo em que se vai desafiando o grupo comunitário a pensar sua história social, como a experiência igualmente social de seus membros, vai revelando a necessidade de superar certos saberes às vezes equivocados, como, por exemplo, àqueles que lhes são ideologicamente inculcados para que se culpem de seu próprio sofrimento ou destino. Viver sem enxergar além do que está por trás das falsas ideologias midiáticas pode reproduzir as perversidades do sistema social, econômico e político em que se encontram inseridos, o que perpetua o poder sistêmico que viola sua dignidade (FREIRE, 1996, p. 32-41).

Assim, as lições deixadas por esse educador merecem está presentes no contexto prático das decisões sobre as questões de saúde, a partir da escuta dos saberes comunitários do povo simples das periferias, com o fim de possibilitar uma revolução democrática da sociedade.

Alerta Paulo Freire que:

Se, na verdade, o sonho que nos anima é democrático e solidário, não é falando aos outros, de cima para baixo, sobretudo, como se fôssemos os portadores da verdade a ser transmitida aos demais, que aprendemos a escutar, mas é escutando que aprendemos a ferir com eles. Somente quem escuta paciente e criticamente o outro, fala com ele. Mesmo que, em certas condições, precise de falar a ele. O que jamais faz quem aprende a escutar para poder falar com é falar impositivamente. [...] O educador que escuta aprende a difícil lição de transformar o seu discurso, às vezes necessário, ao aluno, em uma fala com ele. (1996, p. 43, grifos do autor). 
É por isto que um dos aspectos que mais assustava Freire (1996), igualmente contestado por Foucault (2008), quando este se manifestou sobre o nascimento da biopolítica, refere-se à:

[...] insistência com que, em nome da democracia, da liberdade e da eficácia, se vem asfixiando a própria liberdade e, por extensão, a criatividade e o gosto da aventura do espírito. A liberdade de mover-nos, de arriscar-nos vem sendo submetida a uma certa padronização de fórmulas, de maneiras de ser, em relação às quais somos avaliados. É claro que já não se trata de asfixia truculentamente realizada pelo rei despótico sobre seus súditos, pelo senhor feudal sobre seus vassalos, pelo colonizador sobre os colonizados, pelo dono da fábrica sobre seus operários, pelo Estado autoritário sobre os cidadãos, mas pelo poder invisível da domesticação alienante que alcança a eficiência extraordinária no que venho chamando 'burocratização da mente'. (FREIRE, 1996, p. 43).

Esse poder invisível que envolve a todos e instrumentaliza a vida, exige a revolução social a partir da formação da pedagogia da autonomia libertadora do humano, precisamente daqueles grupos comunitários que se encontram esquecidos pelos poderes público e econômico. É a partir dessa autonomia libertadora e da participação democrática que se podem construir novas pontes ao desenvolvimento do Estado Democrático de Direito que se perfaz pela consecução da efetivação dos direitos fundamentais e humanos.

Nesse sentido, Ana Freire (2019, p. 15), utilizando as categorias criadas por seu esposo Paulo Freire, adverte ser essencial "dignificar as gentes, as pessoas, é, assim, a substantividade dos direitos humanos. São os direitos humanos garantidos e postos em prática que possibilitam que Seres Menos se façam, por direito ontológico, Seres Mais".

O Poder Judiciário, ao encontrar congestionado com inúmeras demandas reclamando à tutela do direito à vida, pode ser o articulador desse processo dialógico entre os operadores do direito e à sociedade, mediado pela parceria da universidade que, como propulsora do conhecimento, não pode ficar de fora desse processo revolucionário do saber, da democracia, da vida e dos direitos humanos.

O que se está propondo neste estudo, para a melhoria da prestação jurisdicional e do planejamento das políticas públicas no âmbito dos serviços de saúde no Brasil, é que a proposição da justiça democrática de aproximação, defendida por Santos (2007), e a pedagogia da autonomia libertária, sugerida por Freire (1996), possam caminhar de mãos dadas no desenho de plataformas que fomentem programas de cunho pedagógico, debates sobre temas jurídicos importantes para sociedade, como por exemplo, a inserção da participação democrática da população nos assuntos de interesse público (orçamento participativo), consubstanciando espaços de diálogos entre os órgãos da justiça e os atores sociais (SANTOS, 2007, p. 86).

Como deve acontecer esse diálogo? Para Freire (2019, p. 141), o verdadeiro diálogo requer que ocorra numa relação horizontal entre os poderes públicos constituídos e a sociedade, originária de uma matriz crítica e que gera criticidade. Assim, enfatiza o autor que esse diálogo:

"Nutre-se do amor, da humildade, da esperança, da fé, da confiança. Por isso, só o diálogo comunica. E quando os dois polos do diálogo se ligam assim, como amor, com esperança, com fé um no outro, se fazem críticos na busca de algo. Instala-se, então, uma relação de simpatia entre ambos. Só aí há comunicação.”. (FREIRE, 2019, p. 141). 
Com isso, é possível verificar que as práticas formativas, idealizadas por Paulo Freire (1196), podem constituir uma excelente plataforma para o Poder Judiciário trabalhar o acesso à saúde quando essas questões forem judicializadas. O que permitirá que por meio do diálogo crítico/construtivo o poder público e a sociedade possam com eficiência e eficácia otimizar os serviços de saúde no Brasil.

\section{CONSIDERAÇÕES FINAIS}

Este artigo propôs-se examinar as barreiras do acesso à saúde no Brasil, de modo a identificar possíveis causas de sua judicialização e plataformas gerenciais de otimização dessas políticas públicas.

Os resultados apontados pelos referenciais teóricos interdisciplinares revelaram, a princípio, que esse fenômeno está intrinsecamente ligado à constitucionalização de novos direitos albergados pela Declaração Universal de Direitos Humanos de 1948 e, no caso do Brasil, pela Constituição Federal de 1988; o aumento da demanda por justiça e a ascensão institucional do Judiciário.

O reconhecimento dos direitos fundamentais pela nova ordem jurídica brasileira representa uma conquista da luta dos movimentos sociais organizados, que resistiram contra um Estado militar que imperava na época, no comando de violações aos direitos humanos, especialmente nos períodos ditatoriais, com destaque 1968 a 1972, onde foram suprimidos todos os direitos civis durante a ditadura militar.

Se a consagração constitucional dos novos direitos decorreu da participação popular em busca de um país mais democrático, solidário e justo, também, para que esses direitos venham a ser efetivados nas relações sociais do cotidiano das pessoas, torna-se necessária a reengenharia do aparelhamento do Estado e o desenvolvimento de novos mecanismos de justiça que estimulem a participação democrática da população nos planos de ação estatal que se referem ao interesse coletivo, para a promoção da qualidade dos serviços públicos, no âmbito da saúde, que permitam a inclusão das classes sociais a usufruírem igualmente dos direitos mínimos consagrados no ordenamento jurídico.

Além dos fatores identificados como causadores do aumento das demandas judiciais, os conectivos teóricos revisados, apontaram, também, certa preocupação com a globalização neoliberal que, ao defender a racionalidade do mercado, fragiliza instituições públicas, que não conseguem gerenciar as políticas públicas sociais mínimas à vida saudável, o que demonstra a existência de uma crise política instalada em parte das instituições do Estado, especialmente dos países em desenvolvimento, como no caso brasileiro.

O processo de racionalidade do mercado expande os espaços privados que flexibilizam direitos sociais e reforçam a instrumentalização da vida humana. Trata-se da administração de um novo paradigma de poder, chamado por Foucault de biopoder, que consiste na preservação da vida humana, mas para dela tirar todas as suas energias em favor do capital financeiro.

Esses fatores têm consequências gravosas para o Estado Democrático de Direito e para a promoção dos direitos humanos. A sociedade vive momentos de incertezas e inseguranças, em decorrência de violações à dignidade da pessoa humana. Os meios de comunicação chegam à perversidade nas suas informações diárias que propagam o medo e o terror. Parcela considerável de crianças e de adolescentes, desassistidos da proteção familiar e do Estado, 
encontram-se reféns do crime organizado ou do tráfico de drogas. Isto representa a ressuscitação do Estado totalitário.

As barreiras, que impactam a qualidade das políticas de saúde, apontam para a necessidade de novos mecanismos de acesso à justiça, que ampliem a participação da sociedade nos planos de ações do Estado de interesse coletivo; que estimulem os membros da comunidade a atuarem como voluntários nos conselhos locais; especialmente que incentive a comunidade a dirimir suas próprias contendas sem necessidade do processo judicial, mediante a conciliação, a mediação e a arbitragem.

Assim, na visão educacional de Freire (1996), a autonomia libertadora do humano perpassa pelos saberes necessários à prática educativa (formativa), que respeitem os saberes populares; o ensino por meio da escuta, mas que vai além disso, ou seja, torna-se indispensável discutir com os membros das comunidades a razão de ser de alguns saberes para a transformação do ambiente social em que vivem, aproveitando as experiência vivenciadas pelos autores sociais para a reconstrução ou renovação de sua história, a partir das possibilidades criadas pelos próprios membros locais que dialogam entre si.

Com isso, as práticas formativas, intermediadas pelo Poder Judiciário, podem consistir numa plataforma de otimização da prestação jurisdicional à minimização da judicialização das demandas individuais de saúde e a melhoria dessas políticas públicas essenciais à vida com dignidade.

\section{REFERÊNCIAS}

AGAMBEN, Giorgio. Estado de exceção. Trad. de Iraci D. Poleti. São Paulo: Boitempo, 2004.

APPIO, Eduardo. Controle judicial das políticas públicas no Brasil. 6. reimpr. Curitiba: Juruá, 2011.

BARROSO, Luís Roberto. O controle de constitucionalidade no direito brasileiro. São Paulo: Saraiva, 2012.

Curso de Direito Constitucional contemporâneo: os conceitos fundamentais e a construção do novo modelo. 3. ed. São Paulo: Saraiva, 2011.

- Judicialização, Ativismo Judicial e Legitimidade democrática. Revista [Syn]Thesis, Rio de Janeiro, vol.5, no 1, 2012, p.23-32. Disponível em:<file:///C:/Users/Vitoria/AppData/Local/Packages/Microsoft.MicrosoftEdge_8wekyb3d8bbwe/TempState/Downloads /7433-26284-1-SM\%20(1).pdf>. Acesso em: 31 out. 2019.

BESTER, Gisela Maria. Dezesseis anos de Constituição Federal, STF e interpretação retrospectiva: prejuízos aos direitos fundamentais pela falta de vontade de Constituição. In: ROCHA, Fernando Luiz Ximenes; MORAES; Filomeno. Direito Constitucional contemporâneo - Estudos em homenagem ao professor Paulo Bonavides. Belo Horizonte: Del Rey, 2005a. p. 333-359.

Direito Constitucional. V. 1. Fundamentos Teóricos. Barueri, SP: 2005b.

BONAVIDES, Paulo. Teoria constitucional da democracia participativa - por um Direito Constitucional de luta e resistência, por uma nova hermenêutica, por uma repolitização da legitimidade. 3. ed. São Paulo: Malheiros, 2008.

BRASIL. Constituição da República Federativa do Brasil, 1988. OLIVEIRA, Juarez de (Org. do texto). São Paulo: Saraiva, 1988. 
BRASIL. Conselho Nacional de Justiça (CNJ). Disponível em: <https://www.cnj. jus.br/agendas/audiencia-publica-sobre-prestacao-da-jurisdicao-em-processos-relativos-asaude/ $\geq$. Acesso em 11 set. 2019.

. Supremo Tribunal Federal (STF). Disponível em: <http://stf.jus.br/portal/ge$\mathrm{ral} /$ verimpressao.asp $>$. Acesso em: 11 set. 2019.

Tribunal de Contas da União (TCU). Disponível em: <https://portal.tcu.gov.br/saude/governanca-em-saude/>. Acesso em. 31 out. 2019.

CAPPELLETTI, Mauro; GARTH, Bryant. Acesso à justiça. Reimpressão. Porto Alegre: SAFE, 2002.

BRASIL. Caos na saúde. Disponível em:< https://www.acessaber.com.br/wp-content/uploads/2016/03/interpretacao-de-texto-charge-caos-na-saude-publica- ${ }^{\circ}{ }^{\circ}$-ano-ensinomedio.pdf>. Acesso em 31 out. 2019.

COSTA, Alexandre Bernardino et al. (Orgs.). O direito achado na rua: uma introdução ao direito à saúde. Brasília: CEAD/UnB, 2009.

DELGADO, Maurício Godinho. Curso de direito do trabalho. 14. ed. São Paulo: LTr, 2015. FARHI NETO, Leon. Biopolítica em Foucault. 2007. 144 f. Dissertação (Mestrado em Filosofia)- Universidade Federal de Santa Catarina, Florianópolis, 2007. Disponível em: < https:/ / repositorio.ufsc.br/handle/123456789/90412>. Acesso em 31 out. 2019.

FOUCAULT, Michael. Microfísica do poder. Trad. de Roberto Machado. 4. ed. Rio de Janeiro: Graal, 1984.

Nascimento da biopolítica: curso dado no Collège de France (1978-1979). Trad. de Eduardo Brandão. São Paulo: Martins Fontes, 2008.

. Vigiar e Punir. Trad. de Raquel Ramalhete. 38. ed. Petrópolis, RJ: Vozes, 2010.

FREIRE, Paulo. Pedagogia da autonomia: saberes necessários à prática educativa. 25. ed. São Paulo: Paz e Terra, 1996.

. 1921-1997. Direitos humanos e educação libertadora: gestão democrática da educação pública na cidade de São Paulo. (Orgs) Freire, Ana Maria Araújo e MENDONÇA, Erasto Fortes. 1. ed. Rio de Janeiro: Paz e Terra, 2019.

. Educação como prática da liberdade. 45a ed. São Paulo: Paz e Terra, 2019.

GABRIEL O PENSADOR. Sem saúde. 1997. Disponível em: <https://www.letras.mus.br/gabriel-pensador/96124/>. Acesso em: 31 out. 2019.

GUIMARÃES, Aline Amorim Melgaço. Democracia possível: espaços institucionais, participação social e cultural política. Campinas, SP: Alínea, 2008.

HABERMAS, Jürgen. Mudança estrutural da esfera pública: investigação sobre uma categoria da sociedade burguesa. Trad. de Denilson Luís Werle. São Paulo: Unesp, 2014.

HARDT, Michael; NEGRI, Antonio. Império. Trad. de Berilo Vargas. 2. ed. Rio de Janeiro: Record, 2001.

HESSE, Konrad. A força normativa da Constituição. Trad. de Gilmar Ferreira Mendes. Porto Alegre: SAFE, 1991.

LAFER, Celso. A reconstrução dos direitos humanos: um diálogo com o pensamento de Hannah Arendt. São Paulo: Companhias das Letras, 1989.

LOPES, Luiz Fernando. Medicalização de crianças com queixa escolar e o Núcleo de Apoio à Saúde da Família (NASF): uma análise crítica. Disponível em:

<http://www.teses.usp.br/teses/disponiveis/47/47131/tde-12072013-113747/pt-br.php>. Acesso em: 31 out. 2019. 
O PENSADOR. Sem saúde. Disponível em: <https://www.letras.mus.br/gabriel-pensador/96124/>. Acesso em: 31 out. 2019. [deletado]

PÁDUA, Thiago Aguiar. A expressão "ativismo judicial", como um "clichê constitucional", deve ser abandonada: uma análise crítica. Revista Brasileira de Políticas Públicas, UniCEUB, Brasília, v. 5, n. especial, p. 135-168, 2015.

PERIUS, Oneide. Walter Benjamin a filosofia como exercício. Passo Fundo, RS: IFIBE, 2013.

PIOVESAN, Flávia. Direitos humanos e o Direito Constitucional Internacional. 13. ed. São Paulo: Saraiva, 2012.

RUIZ, Castor M. M. Bartolomé. A vida humana e o estado de exceção: a tentação totalitária do controle biopolítico. In: DORNELLES, João Ricardo Wanderley; GRAZIANO SOBRINHO, Sergio Francisco Carlos (Orgs.). Estado, política e Direito: políticas públicas e direitos humanos. V. 2. Criciúma, SC: UNESC, 2013. p. 27-51.

SANDEL, Michael. O que o dinheiro não compra: os limites morais do mercado. Trad. Clóvis Marques. 5. ed. Rio de Janeiro: Civilização Brasileira, 2013.

SANTOS. Boaventura de Sousa. Democratizar a democracia: os caminhos da democracia participativa. Coleção Reinventar a Emancipação Social, v. 1. Rio de Janeiro: Civilização Brasileira, 2002.

Reinventar a democracia. 2. ed. Lisboa: Gravida, 2002.

Para uma revolução democrática da Justiça. São Paulo: Cortez, 2007.

Direitos humanos, democracia e desenvolvimento. São Paulo: Cortez, 2013.

SARLET, Ingo Wolfgang. A eficácia dos direitos fundamentais. Porto Alegre: Livraria do Advogado, 2005.

SARMENTO, Daniel. Direitos fundamentais e relações privadas. Rio de Janeiro: Lumen Juris, 2004.

Livres e iguais: estudos de direito constitucional. Rio de Janeiro: Lumen Juris, 2006.

VELOSO, Juliano Ribeiro Santos. Direito ao planejamento. Belo Horizonte: D’Plácido, 2014.

THIESEN, Juares da Silva. A interdisciplinaridade como um movimento articulador no processo ensino-aprendizagem. Rev. Bras. Educ., Rio de Janeiro, v. 13, n. 39, p. 545-554, Dec. 2008. 